UDC 340.132.1

Shopina Iryna,

Doctor of Juridical Sciences, Full

Professor, Professor at the Department

of Administrative and Legal Disciplines

of Lviv State University of Internal

Affairs MIA Ukraine

ORCID ID 0000-0003-3334-7548

\title{
DEVELOPMENT OF LEGAL CULTURE IN MODERN CONDITIONS OF STATE FORMATION
}

Research paper studies the features of legal culture phenomenon in modern Ukrainian society. The author identifies three groups of factors that have a negative impact on the level of legal culture. The first group of factors is related to the behavior of national elites and the psychological mechanism of imitation. The second group of factors is due to the influence of information technologies and the emergence of numerous "alternative" realities. The third group of factors is related to the activities of large corporations in the implementation of their marketing strategies, the purpose of which is to stimulate certain consumer behavior. The author considers the possibilities of adjusting the influence of these groups of factors and overcoming the tendencies of legal nihilism in Ukrainian society.

Special attention is drawn to the analysis of legal culture of military men. The author defines the legal culture of a serviceman as the totality of his legal values, legal knowledge, skills that together determine his legal behavior. The paper considers five levels of legal culture of servicemen distinguished on the basis of empirical research.

Paper contains the following conclusions from the results of the study. The constant decline in the role of law as a universal regulator of public relations is a characteristic feature of a metamodern society. However, this does not mean the movement of human civilization towards chaos and anarchy. At the same time, the importance of transparency of financial transactions, movement in space, activity on 
the Internet is increasing. Society is becoming more transparent, the mechanism of compliance with legal regulations is changing. A person can follow the regulations of law without knowing or understanding them. The methods of verbal reproduction of views on the values of legal culture and legal behavior in such conditions are ineffective and will always reproduce with other influences on personality behavior.

Keywords: legal culture, legal behavior, legal awareness, imitation, narrative, information technology.

\section{REFERENCES}

1. Iak vymiriaty efektyvnist kreatyvu? "How to Measure Creative Effectiveness?" URL: https://www.slideshare.net/saksonia/moneyveo-138144388 (date of application: 11.09.2019) [in Ukrainian]

2. Lytvynov O. M., Orlov Yu. V. (2019) Narysy z kryminolohii postmodernu. "Essays on Criminology Postmodern Kharkiv". Kharkiv : Pravo. 278 p. [in Ukrainian]

3. Skurikhin S. M. (2003) Osoblyvosti pravovoi kultury viiskovosluzhbovtsiv. "Features of Legal Culture of Servicemen". Actual Issues of the State and Law. 2003 [in Ukrainian].

4. Syvak O., Durach V. (2007) Vykhovannia pravovoi kultury viiskovosluzhbovtsiv - nevidkladne zavdannia kadrovoi polityky u Zbroinykh sylakh Ukrainy. "Education of the Legal Culture of Military Personnel as an Urgent Task of Personnel Policy in the Armed Forces of Ukraine". The Ukrainian National Idea: Realities and Prospects for Development. P. 90-95 [in Ukrainian]. 